\title{
Transatlantica
}

Revue d'études américaines. American Studies Journal

\section{Dennis Tredy, Annick Duperray and Adrian Harding, eds., Henry James and the Poetics of Duplicity}

\section{Roxana Oltean}

\section{(2) OpenEdition}

1 Journals

\section{Electronic version}

URL: https://journals.openedition.org/transatlantica/6317

DOI: $10.4000 /$ transatlantica.6317

ISSN: 1765-2766

\section{Publisher}

Association française d'Etudes Américaines (AFEA)

\section{Electronic reference}

Roxana Oltean, "Dennis Tredy, Annick Duperray and Adrian Harding, eds., Henry James and the Poetics of Duplicity", Transatlantica [Online], 1 | 2013, Online since 15 December 2013, connection on 31 January 2023. URL: http://journals.openedition.org/transatlantica/6317 ; DOI: https://doi.org/10.4000/ transatlantica.6317

This text was automatically generated on 31 January 2023.

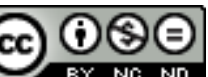

Creative Commons - Attribution-NonCommercial-NoDerivatives 4.0 International - CC BY-NC-ND 4.0 https://creativecommons.org/licenses/by-nc-nd/4.0/ 


\title{
Dennis Tredy, Annick Duperray and Adrian Harding, eds., Henry James and the Poetics of Duplicity
}

\author{
Roxana Oltean
}

\section{REFERENCES}

Dennis Tredy, Annick Duperray and Adrian Harding, eds., Henry James and the Poetics of Duplicity, Newcastle upon Tyne, Cambridge Scholars Publishing, 2013, ISBN 978-1443844178, £44.99.

1 A new volume of essays published in 2013 by Cambridge Scholars Publishing brings together articles addressing the theme of duplicity, a veritable "poetics" of the Jamesian œuvre, as Dennis Tredy argues in the Preface, indicating, after an inventory of deceits in some of the Jamesian works that are most often at the fore of critical attention, that structures of duplicity work in an array of subtle ways in the Jamesian fictional and nonfictional fabric. As discussed in the Preface, and in the volume per se, duplicity becomes a topic that cogently puts into dialogue a series of issues Jamesian scholars have indexed before-from revision to return, from ambivalence to rewriting, from lying to fictionalisation-and the effort to organize the various facets of duplicity into five distinct sections in the present volume, in a highly cogent and logical structure, does a wonderful work of systematization for topics of research and inquiry which might otherwise appear disparate. This is emphasized by the fact that the articles are presented as chapters of a single work. In this sense, given that, by highlighting the notorious Jamesian ambivalence, there is a danger of entering upon the territory of confusions worse confounded, as any critical argument about James can be overturned, the immense critical work performed by the very premises of this volume is to emphasize duplicity as a recurrent motif and as a Jamesian strategy that, by confounding the reader, enlightens us into a more complex understanding, avoiding, at the same time, the pitfalls of a fully open, anything-goes reading. While the 
articles themselves evince quite a range in critical experience, depth of inquiry and extent of research, the high variety of the perspectives presented, as well as the editorial achievement of bringing and organizing these so as to meaningfully reflect on meanings of duplicity, will certainly make this volume a reference point in James research on the European and international scene.

2 One of the main stakes of the critical approaches presented here is to go beyond the more overt manifestations of duplicity in James's fiction, remembered by Tredy in the Preface ("duplicitous characters and narrators, the presence of doubles and doppelgängers, duplicitous narrative techniques and double narrative set-ups," xiv) and also to delve into Jamesian duplicity in the works of non-fiction, (biographies, autobiographies, reviews, letters, notebooks), while also attempting to meaningfully account for James's contradictions (for example, contradictory remarks about other writers, such as Edmond de Goncourt) or poetic rewritings of letters written by his father or brother. In view of systematizing the full spectrum of possible approaches to, and meanings of, duplicity, the editors have divided the articles-chapters-into five thematic clusters illuminating the implications of duplicity: "Duplicitous Subtexts," "Duplicitous Characters," "Duplicitous Representation," "Duplicitous SelfRepresentation," "Duplicitous Judgments." While it is impossible in the space available to do justice to all the articles comprising this volume, the lines that follow will attempt to give an impression-hopefully in a fuller, Jamesian sense-of the breadth of interpretations brought forth here, and of the Jamesian themes this volume builds upon or opens up.

3 Part 1, "Duplicitous Subtexts," reopens the vexed question of Jamesian sources of inspiration-"underhanded 'duplication' " (xvi), as the editors put it. It is a section only consisting of two chapters, by two established James scholars-Jean Perrot, who discusses a possible source text for The Turn of the Screw and Sergio Perosa, investigating Shakespearean notes in James's writing. A particularly engaging interpretation is that put forth by Jean Perrot, who identifies a source text for The Turn of the Screw and who also compellingly argues for what one might call the ghostly presence of this text in James's writings in the period from 1870-1871 to the end of the century. In observance of the art of suspense cultivated in the article, the source will not be mentioned here, but suffice it to say that, with a comparative analysis of plots and stories, and a painstaking investigation into "minute elements of the writing itself" (7), including the "systematic process of double entendre" through the governess's unreliable narration (14), the article not only convincingly argues for the relevance of the specific source text, but also stresses James's poetic reversals, heightening, we might add, the relevance of the quotation from the source text, as well as a modern emphasis on the process of quotation itself. It would be possible, taking up the lead of what Perrot calls James's "tongue-in-cheek" writing (James "twisted his humorous treatment of the grotesque so as to reach what remains an ironical conclusion," 17) to point, even further, to a series of techniques through which James indicates his own artifice, in a modern adumbration of the work of art as spectacular in its aesthetic overkill. The game of hiding and revealing the source, evinced in the article, can thus be read as part of an ampler Jamesian manifestation of a modern consciousness.

Part 2, "Duplicitous Characters," brings together a focus on the reciprocity of deceit in "The Lesson of the Master," where duplicity is refracted into "secrecy and clandestinity" as well as "mastery, domination and power" (47) (Thomas 
Constantinesco) and in The Golden Bowl, inscribed in a transactional logic (Agnès PokolHayhurst), with the investigation of the veritable art of deceit in the less discussed but highly relevant "The Liar" (Keiko Beppu), showing the conjunction between deceit and techniques of transmission of the unwritten or unsaid (John Holland) or, as in Angus Wrenn's text, investigating an imagined dialogue with Emile Durkheim's sociological theories, in particular the idea of dual nature. A promising line of investigation is that explored in Richard Anker's piece, which juxtaposes Nietzsche's notion of bad conscience and the genealogy of conscience, embroiled with the need to "bear" oneself, and crisis episodes (such as in "A London Life") characterized by "transition from nature to culture, from pre-linguistic being to the symbolic order of society" (57). Duplicity-in particular the duplicity of bad conscience at the basis of the aesthetic impulse-would originate in this lack of nature, Anker's argument runs.

Part 3, "Duplicitous Representation," takes duplicity into the wider sphere of narrative elements, and this direction receives fresh accents here, for example in the opening piece by Eric Savoy, who stresses the change from duplicity as performance in the early works (the machinations and lies told to the protagonist in The American, for example) to duplicity inscribed in a performative register in the late works, emerging as "radical uncertainty" and as a "specific and localised speech act" (103), thus displacing attention from character to discourse, blurring ethical situations and queering discourse-Savoy reads "queerness" as "placeholder to connote the inexplicable, the paradoxical, the experience that is not subject to narrative recounting" (105). Correlated with the poetics of Jamesian return or reprise, Savoy links the Jamesian "loss and renunciation" (109) in The Ambassadors or "The Jolly Corner," but also the later Jamesian "duplicitous plenitude of return" (109) to Kierkegaard's trajectory of return to subjective wholeness and to Freud's death drive to ultimately indicate the impossibility of "la reprise." If Savoy argues that this suggests the "impossibility of the subject," it might also be relevant to add that this returns us to nostalgia as a preferred Jamesian subject, as well as to an awareness of the state of thrown-ness into the world, as other recent critical developments show (see for example A Historical Guide to Henry James, edited by John Carlos Rowe and John Haralson, Oxford, Oxford University Press, 2012). The section continues with the ramifications of duplicitous representation and exchange, for example as a form of "double consciousness" (Rebekah Scott's analysis), or as compounded with a mutable exchange value (Madeleine Vala) in view of the highly rebellious and opaque character of objects and gifts, while patterns of exchange on the symbolic, psychological and dramatic tier are explored in The Sacred Fount (Victor Geraldo Rivas-Lopez).

6 The first three sections might be said to detail a key facet of Jamesian ambiguity, enriching a highly layered critical and interpretative canvas. It is the last two sections of the volume that bring the theme of duplicity into areas of discussion that spiral out to James's non-fictional milieux. The fourth section on "Duplicitous SelfRepresentation" deals with James's (re)assessments in his self-reflective non-fiction after 1905, with duplicity as a form of creativity and even self-help (Paula Marantz Cohen). James's double lives are an inevitable focus of this section, for example the navigation between fiction and autobiography (Mhairi Pooler), or between art and the material world, anticipating 21st century realities in a way that is "prophetic and germane" (Collin Meissner). Doubling and othering in the racial and ethnic dimension is another theme proposed for investigation, in Madeleine Danova's reading of ghostly 
doublings-the ethnic occult-created by James upon his return to the US and represented in The American Scene, disrupting representations of the real.

7 Section Five, "Duplicitous Judgements," engages perhaps the most volatile topic, that of James's appreciation or criticism of fellow artists. A veritable poetics of duplicity is shown to be at the basis of James's biographies (William Wetmore and HawthorneMiraslawa Buchholtz) or of James's assessment of artist-friends like Alphonse Daudet, conflated with conflicted views of realism and ethical aestheticism (Tomoko Eguchi), the latter topic also pursued by Rosella Mamoli-Zorzi. The closing essay, written in French, draws the readers' attention, as the editors anticipate, not only because it is the work of a practicing psychoanalyst who saw in the strategies of duplicity from "The Pupil" a solution to make progress with her own patient, but also because the essay wonderfully shows the power of duplicity to create a fiction that mobilizes psychical realities, constituting living proof, as it were, of duplicity as a strategy. Perhaps unintentionally, when speaking of what Henry James teaches the analyst, Johanna Lasry provides a compelling description of duplicity which can act as a "working" definition in more ways than one-"working" because it is functional, provisional, open to silence and to rewriting, yet compelling in its provisory status. Thus reflecting on the lesson of Henry James discernible from "The Pupil," in particular, Lasry mentions "une certaine manière d'écouter les vacillements d'un signifiant, de ne pas enfermer le sens d'un mot ou d'un silence" (219). In a sense, writes Lasry, the lesson of duplicity learnt from Henry James provided an exit from the deadlock of transference and, by extension, the deadlock of reading, communication, by productive strategies of duplicity. Following Felman's reading of the vulgarity of texts as being that which is frozen in the literal, Lasry emphasizes the importance of the malaise given by the disruption of sense and offers a glimpse of a reader/analyst "dans une disposition d'accueil et d'écoute des effets d'un silence, d'une absence ou d'une parole dans sa pluralité signifiante" (225).

8 To what extent are duplicity and doubling a form of communication that allows for plurality without undermining meaning altogether? Many of the points of view drawn together by this volume evince possible answers that are sensitive to Jamesian nuance and intricacy. The space of duplicity, largely emptied of its negative ethical connotations, appears as a place of repose and respite. In The Ivory Tower, Rosanna muses that "You couldn't retire without something or somewhere to retire to, you must have planted a single tree at least for shade or be able to turn a key in some yielding door" $(I T, 4)$. It is the merit of the present volume that it presents readers, students and scholars of James with a series of yielding doors into a dense textual fabric.

JAMES, Henry, The Ivory Tower, ed. Percy Lubbock, The Novels and Tales of Henry James, vol. XXV, 26 vols., New York, Charles Scribner's Sons, 1945 [1917].

ROWE, John Carlos and Eric HARALSON, eds., A Historical Guide to Henry James, Oxford, Oxford University Press, 2012. 


\section{AUTHORS}

ROXANA OLTEAN

University of Bucharest 